\section{AGRIEKONOMIKA}

http://journal.trunojoyo.ac.id/agriekonomika

Volume 9, Nomor 1, 2020

https://doi.org/10.21107/agriekonomika.v9i1.7346
Agriekonomika has been accredited as a scientific journal by the Ministry of

Research-Technology and Higher Education Republic of Indonesia: No. 23/E/KPT/2019

\title{
Permintaan Kopi Biji Indonesia di Pasar Internasional
}

\author{
${ }^{凶 1}$ Doni Sahat Tua Manalu, ${ }^{2}$ Harianto, ${ }^{2}$ Suharno dan ${ }^{2}$ Sri Hartoyo \\ ${ }^{1}$ Program Studi IImu Ekonomi Pertanian Pascasarjana IPB University, Indonesia \\ ${ }^{2}$ Program Studi Ekonomi Pertanian Pascasarjana IPB University, Indonesia \\ Received: January 2020; Accepted: April 2020; Published: April 2020
}

\begin{abstract}
ABSTRAK
Kopi merupakan salah satu komoditas unggulan perkebunan Indonesia setelah kelapa sawit, karet dan kakao dengan jumlah ekspor kopi yang lebih tinggi dibandingkan dengan konsumsi domestik. Tujuan penelitian adalah menganalisis faktor-faktor yang memengaruhi permintaan kopi biji Indonesia di pasar Internasional. Metode analisis data yang digunakan pada penelitian ini adalah model Linear Approximate Almost Ideal Demand System (LA/AIDS) dengan menggunakan data time series dari tahun 1995 hingga 2017 dengan HS 090111. Hasil penelitian menunjukkan bahwa faktor-faktor yang memengaruhi permintaan kopi biji Indonesia di Amerika Serikat adalah harga kopi row, Carea NTM, di Jepang adalah harga kopi Vietnam, populasi Jepang dan NTR Jepang terhadap Dollar, di Jerman adalah harga row dan Carea NTM. Kopi Indonesia bersifat elastis di negara importir utama Amerika Serikat, Jepang dan Jerman. Berdasarkan nilai elastisitas silang kopi Indonesia bersifat inelastis, kopi Indonesia bersifat komplementer dengan kopi Vietnam di pasar Amerika Serikat, sementara di pasar Jepang dan Jerman bersifat substitusi.
\end{abstract}

Kata Kunci : AIDS, Kopi biji, Perdagangan, Permintaan

\section{Demand of Indonesian Coffee Beans in International Market}

\begin{abstract}
Coffee is one of the leading commodities of Indonesian plantations after oil palm, rubber and cocoa with a higher amount of coffee exports compared to domestic consumption. The research objective is to analyze the factors that influence the demand for Indonesian coffee beans in the international market. The data analysis method used in this study is the Linear Approximate Almost Ideal Demand System (LA / AIDS) model using time series data from 1995 to 2017 with HS 090111. The results showed that the factors affecting the demand for Indonesian coffee beans in USA are row coffee prices, Carea NTM, in Japan are Vietnamese coffee prices, Japanese population and Japanese NTR against the Dollar, in Germany are row coffee prices and Carea NTM prices. Indonesian coffee is elastic in the main importing countries of the United States, Japan and Germany. Based on the cross elasticity value of Indonesian coffee is inelastic, Indonesian coffee is complementary with Vietnamese coffee in the United States market, while in Japan and Germany the market is substitution.
\end{abstract}

Keywords: AIDS, coffee beans, Trade, Demand

\section{PENDAHULUAN}

Komoditas unggulan ekspor Indonesia dari sub sektor perkebunan salah satunya adalah kopi setelah kelapa sawit, karet dan kakao dengan jumlah ekspor kopi yang lebih tinggi dibandingkan dengan

\footnotetext{
Corresponding author :

Email : manaludoni@gmail.com

Phone : 081362014272
} 


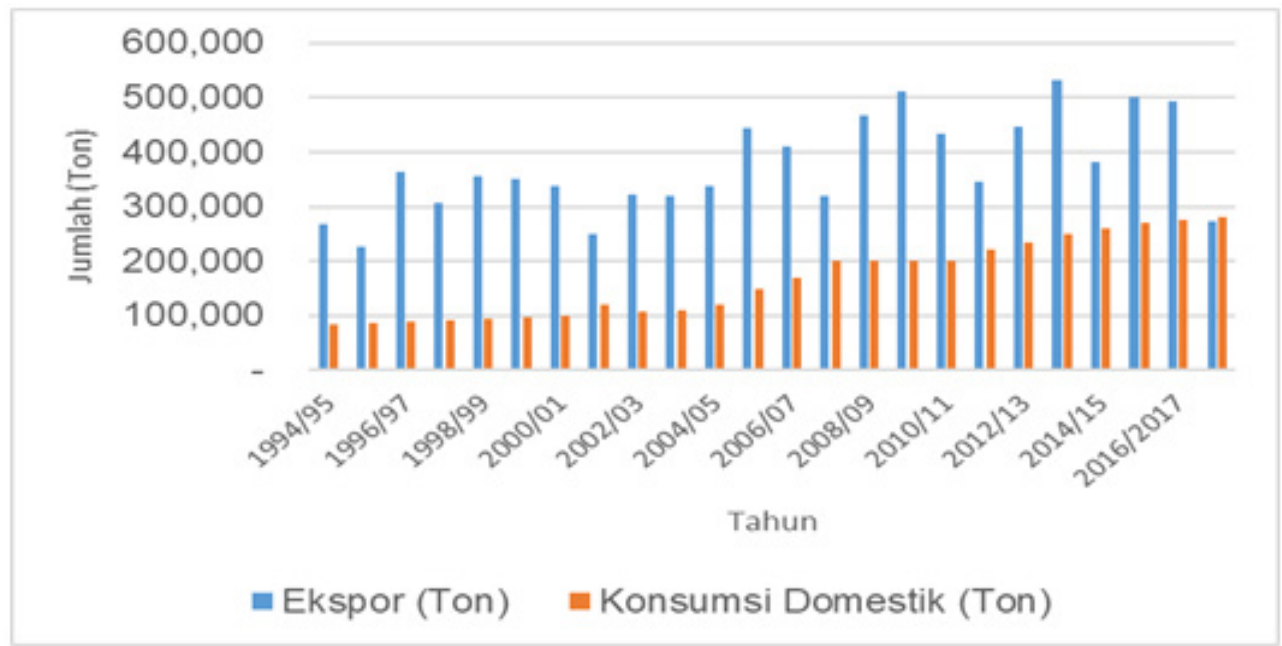

Sumber : ICO, 2019

\section{Gambar 1 \\ Jumlah Ekspor (Ton) dan Konsumsi Domestik (Ton) Kopi Biji Indonesia Tahun 1994/1995-2017/2018}

konsumsi domestik seperti terdapat pada Gambar 1.

Produksi kopi Indonesia berada pada urutan keempat setelah Brazil, Vietnam dan Colombia dengan output produksi mencapai 654.000 ton pada tahun 2017 atau sama dengan 6,84 persen produksi kopi dunia. Sementara itu, negara tujuan ekspor kopi Indonesia tersebar ke berbagai wilayah di dunia seperti Eropa diikuti oleh Asia dan Amerika Serikat (UN Comtrade, 2019). Sementara jenis kopi di dunia dari keempat negara eksportir utama adalah 2 jenis yaitu robusta dan arabika, Adapun negara yang memproduksi lebih dominan kopi robusta (produsen kopi rosbusta) adalah Indonesia dan Vietnam sementara negara produsen kopi arabika adalah Brazil dan Colombia (ICO, 2019).

Kementerian Pertanian (2015), mencatat bahwa permintaan kopi di pasar Internasional diprediksi akan terus meningkat seiring dengan meningkatnya konsumsi kopi dunia. Pada tahun 20182019 konsumsi kopi dunia diperkirakan meningkat sebesar 9,911 juta ton, hal tersebut menunjukkan bahwa terjadi peningkatan sebesar 2,1 persen dibandingkan dengan tahun 2017-2018. Konsumsi domestik pada negara eksportir juga diperkirakan meningkat sebesar 1,4 persen (50,3 juta kantong). Demikian halnya dengan jumlah konsumsi di negara importir diperkirakan naik sebesar 2,5 persen (6,893 juta ton). Sementara pada tahun 2018-2019, produksi kopi dunia diperkirakan akan melebihi konsumsi sebesar 2,29 juta kantong. Hal ini menunjukkan bahwa pasar peluang Indonesia untuk meningkatkan ekspor kopi masih cukup potensial, namun di sisi lain perlu diantisipasi persaingan yang tinggi antar negara eksportir kopi dunia, mengingat posisi Indonesia sebagai produsen kopi dunia hanya berada pada posisi ke empat.

Berdasarkan data dari Direktorat Jenderal Perkebunan (Ditjenbun), bahwa dari 4 jenis produk kopi yang diekspor oleh Indonesia, kopi biji memiliki rata-rata volume ekspor paling tinggi, yaitu 437.510 ton. Namun demikian, harga ekspor kopi biji hanya sebesar 2,2 US\$/kg. Berbeda dengan harga kopi bubuk yang mencapai 3,57 US\$/kg, namun volume ekspor hanya 995 ton. Artinya, dominasi ekspor kopi Indonesia bukan dalam bentuk kopi bubuk yang memiliki harga tinggi, namun malah berbentuk kopi biji yang justru harganya paling rendah (Direktorat Jenderal Perkebunan, 2015). 
Kopi Indonesia memiliki daya saing, namun perlu antisipasi agar posisi daya saing tersebut tetap dapat ditingkatkan karena masih lebih rendah dibandingkan daya saing negara eksportir dunia lainnya (Asmarantaka, 2011; Narulita dkk., 2014; Hidayat \& Soetriono, 2010). Lebih lanjut Rosiana (2019), menguraikan bahwa Indonesia sebagai negara terbesar keempat pengekspor kopi di dunia memiliki daya saing kopi yang berfluktuasi selain itu juga terjadi pergeseran posisi pasar ekspor yang dinamis di pasar kopi dunia. Meskipun kopi Indonesia saat ini masih berdayasaing, namun pangsa ekspor kopi Indonesia di pasar internasional semakin menurun. Hal ini disebabkan oleh menurunnya volume ekspor sebesar 2,63 persen per tahun akibat penurunan produksi sebesar 0,61 persen per tahun.

Kementerian Pertanian (2015), mencatat bahwa program pemerintah yang dicanangkan mengenai komoditas kopi tertuang dalam Rencana Pembangunan Jangka Panjang Nasional (RPJPN), pemerintah Indonesia memiliki target peningkatan volume ekspor kopi biji sebesar 24,3 persen atau sebesar 462.497 ton pada tahun 2025 , selain target ekspor, pemerintah juga menargetkan peningkatan konsumsi per kapita sebesar $1,5 \mathrm{~kg}$ per tahun di tahun 2019 yang tercantum dalam Rencana Induk Pembangunan Industri Nasional (RIPIN).

Kemudian dari sisi pasar, hal yang menjadi penentu daya saing kopi Indonesia adalah adanya peraturan yang diterapkan oleh negara importir utama dunia khususnya Jerman, Jepang dan Amerika Serikat seperti isu kontaminasi Ochratoxin A (OTA), Carbaryl, dan biaya ekspor yang relatif tinggi (Kementerian Pertanian, 2017; Almeida dkk., 2012). Peningkatan ekspor kopi Indonesia diprediksi meningkat tahun 2012 hingga 2021 dengan trend pertumbuhan 1,6 persen setiap tahun (Rosiana dkk., 2017). Hal ini akan terwujud apabila pemerintah dan stakeholder terkait dapat melakukan bagiannya masing-masing dengan baik.
Kondisi pasar kopi Indonesai di negara importir utama yang menjadi penentu keberhasilan ekspor Indonesia perlu diketahui, oleh karena itu fokus dari penelitian ini adalah mengetahui faktorfaktor yang memengaruhi permintaan kopi Indonesia di negara importir utama. Analisis dilakukan dengan pendekatan metode Linear Almost Ideal Demand System (LA/AIDS).

Studi empiris yang sudah pernah dilakukan untuk melihat posisi komoditas ekspor suatu negara di negara importir sudah banyak dilakukan sebelumnya, beberapa studi yang menggunakan model AIDS adalah Wilkinson (1981), studinya menemukan pertama kalinya metode analisis untuk menggambarkan sistem permintaan suatu produk dengan metode AIDS dimana metode tersebut mengakomodasi semua hambatan seperti aditivitas, homogenity dan simetri yang dapat diuji dengan statistik. Dalam model AIDS variabel harga merupakan variabel penghubung antara permintaan dan penawaran.

Selain itu, pendekatan model AIDS pernah digunakan oleh Galarraga \& Markandya (2004), untuk mengestimasi permintaan produk berkelanjutan pada studi kasus fair trade dan kopi organik di United Kingdom (UK), pada penelitian yang bertopik perdagangan internasional model AIDS sudah diterapkan oleh beberapa peneliti terdahulu (Gebrehiwot \& Daloonpate, 2012; Rifin, 2010).

Adapun tujuan dari penelitian ini adalah untuk menganalisis permintaan kopi biji Indonesia di pasar internasional dengan melihat faktor-faktor yang memengaruhi permintaan kopi Indonesia di pasar Internasional dan menghitung elastisitas kopi biji Indonesia di pasar internasional.

\section{METODE PENELITIAN}

Jenis data yang dianalisis adalah data sekunder dengan deret waktu (time series) sejak tahun 1995-2017 digunakan dalam penelitian ini dan diperoleh dari berbagai sumber seperti UN Comtrade, 
Kementerian Pertanian, International Coffee Organization (ICO), Jenis kopi yang dianalisis yaitu kopi biji dengan kode HS 090111 (coffee, not roasted, not decaffeinated). Jenis kopi tersebut dipilih karena berdasarkan data bahwa ekspor kopi Indonesia yang terbesar selama periode analisis penelitian sebagian besar dalam bentuk kopi biji (sebesar 99.5 persen). Negara importir dunia (negara tujuan ekspor) yang dipilih adalah Amerika Serikat, Jepang dan Jerman dengan pertimbangan ketiga negara tersebut adalah negara tujuan ekspor kopi Indonesia terbesar.

\section{Metode Analisis Data}

Hasil estimasi dari model AIDS digunakan untuk menjawab masalah faktor-faktor yang memengaruhi permintaan impor kopi Indonesia di negara importir utama dunia. Nilai signifikansi adalah dasar untuk menetapkan variabel yang berpengaruh. Sementara seberapa pengaruh variabel tersebut dapat diketahui berdasarkan nilai koefisien masing-masing variabel dari hasil estimasi.

Pengolahan data diestimasi menggunakan model linear AIDS (LA/AIDS) yang diadopsi dari (Deaton, 1980) dengan model dasar sebagai berikut.

$w_{i}=\alpha_{i}+\sum^{n} \gamma_{i j} \ln p_{j}+\beta_{i} \ln \left(\frac{X}{p^{*}}\right)+\sum \theta \ln Z+e_{i}$

Dimana $\mathbf{W}$ adalah pangsa ekspor negara eksportir ke-i di negara tujuan, $\mathbf{P}$ adalah harga asal negara eksportir, $\mathbf{x}$ adalah nilai impor total negara tujuan, $\mathbf{P}^{*}$ adalah indeks harga geometrik Stone $=$ $\sum \mathbf{w}_{\mathrm{i}} \cdot \mathbf{p}_{\mathrm{i}}$ dan $\mathbf{Z}$ adalah peubah demografi (Coverage area, populasi, GDP riil, inflasi, Nilai tukar riil).

Model permintaan kopi di negara tujuan:

$$
\begin{aligned}
& W_{1}=\alpha_{1}+\gamma_{11} \ln p_{1}+\gamma_{12} \ln p_{2}+\gamma_{13} \ln p_{3}+\gamma_{14} \operatorname{Inp} p_{4} \\
& +\gamma_{15} \ln p_{5}+\beta_{1} \ln \left(\mathrm{x} / \mathrm{P}^{*}\right)+\theta_{1} \text { Carea }+\theta_{2} \text { Pop } \\
& +\theta_{3} \mathrm{GDPR}+\theta_{4} \mathrm{INF}+\theta_{5} \mathrm{NTR} \\
& \mathrm{W}_{2}=\alpha_{2}+\gamma_{21} \ln p_{1}+\gamma_{22} \ln p_{2}+\gamma_{23} \ln p_{3}+\gamma_{24} \ln p_{4} \\
& +\gamma_{25} \ln p_{5}+\beta_{2} \ln \left(\mathrm{x} / \mathrm{P}^{*}\right)+\theta_{1} \text { Carea }+\theta_{2} \text { Pop } \\
& +\theta_{3} \mathrm{GDPR}+\theta_{4} \mathrm{INF}+\theta_{5} \mathrm{NTR}
\end{aligned}
$$

Dimana $\mathbf{W}_{1}$ adalah share ekspor kopi Indonesia di Negara tujuan, $\mathbf{W}_{2}$ adalah share ekspor kopi Vietnam di Negara tujuan, $\mathbf{P}_{1}$ adalah harga kopi Indonesia di negara tujuan, $\mathbf{P}_{2}$ adalah harga kopi Vietnam di negara tujuan Carea adalah Coverage area eksportir di negara tujuan (non tarif impor), Pop adalah Populasi negara tujuan, GDPR adalah Gros Domestic Product Riil negara tujuan, INF adalah Inflasi di negara tujuan, NTR adalah Nilai tukar riil negara tujuan terhadap Dollar dan $\boldsymbol{\alpha}, \boldsymbol{\gamma}, \boldsymbol{\beta}, \boldsymbol{\theta}$ adalah parameter regresi.

Indeks harga geometrik stone dapat memengaruhi perhitungan pada model AIDS, hal ini disebabkan oleh tidak invarian terhadap perubahan unit pengukuran Moschini 1995 dalam Rifin (2011). Maka Moschini mengemukakan bahwa agar indeks harga stone terkoreksi yang menggunakan log-linear versi indeks Laspeyres sebagai berikut.

$\ln P^{*}=\sum_{i=1}^{n} S i \ln \frac{P i t}{P_{t}^{0}}$

Dimana $P_{t}^{0}$ adalah harga di tahun dasar. Selanjutnya, metode Seemingly Unrelated Regression (SUR) yang diolah pada program SAS 14.1 dilakukan untuk menentukan koefisien regresi pada model. Sesuai dengan syarat pada model AIDS maka persamaan-persamaan yang dibangun pada penelitian ini direstriksi menggunakan kendala adding up, homogenity dan symmetry. Tiga restriksi yang harus dimasukkan ke dalam model agar asumsi maksimasi kepuasan dapat terpenuhi adalah:

\section{Aditivitas/Adding Up}

Suatu syarat yang menunjukkan bahwa total pengeluaran pada fungsi permintaan sama dengan total pendapatan. Secara matematis bisa dituliskan sebagai berikut:

$\sum_{i} \alpha_{i}=1, \sum_{i} Y_{i j}=0, \Sigma_{j} \beta i=0$

\section{Homogenitas}

Persyaratan yang menyebutkan bahwa jika pendapatan dan harga berubah dalam proporsi yang sama, maka permintaan terhadap suatu komoditas tidak akan 
berubah. Hal ini merupakan implikasi dari sifat fungsi permintaan yang homogen berderajat nol terhadap harga dan permintaan. Bentuk matematisnya adalah sebagai berikut:

$\sum_{\mathrm{j}} \gamma i j=0$

\section{Simetris}

Berdasarkan parameter-parameter AIDS yang diperoleh dari hasil estimasi maka selanjutnya dihitung nilai elastisitas yang dapat menggambarkan kondisi permintaan kopi biji Indonesia di negara importir kopi utama dunia. Adapun rumus elastisitas uncompensated atau Marshallian pada penelitian ini diadopsi dari penelitian Wan et al (2010) yaitu: (1) elastisitas harga sendiri, (2) elastisitas harga silang, dan (3) elastisitas pengeluaran yang dihitung berdasarkan rumus sebagai berikut:

$Y_{i j}=Y_{j i}$

Elastisitas harga sendiri:

$e_{i j}=\frac{\left(\hat{\mathrm{y}}_{i j}-\beta_{i} w_{i}\right)}{\dot{\mathrm{w}}_{i}}-1$

Elastisitas harga silang

$e_{i j}=\frac{\left(\hat{\mathrm{y}}_{i j}-\beta_{i} w_{j}\right)}{\dot{\mathrm{w}}_{i}} ; i \neq j$

Elastisitas pengeluaran

$\eta_{i}=1+\frac{\beta_{i}}{\dot{w}_{i}}$

Dimana $\hat{y}_{i j}$ adalah parameter harga kopi di pasar $\mathrm{j}, \beta_{i}$ adalah nilai total impor kopi di pasar j, adalah share kopi Indonesia, $w_{j}$ adalah share kopi negara lain.

\section{HASIL DAN PEMBAHASAN}

Nilai Rata-rata Share Kopi Biji Indonesia dan Vietnam di Pasar Amerika Serikat, Jepang dan Jerman Tahun 1995-2017

Berdasarkan hasil analisis yang dilakukan menunjukkan bahwa nilai ratarata share kopi biji Indonesia dan Vietnam di pasar Amerika Serikat, Jepang dan Jerman pada tahun 1995-2017 seperti terdapat pada Tabel 1.
Tabel 1

Nilai Rata-rata Share Kopi Biji Indonesia dan Vietnam di Pasar Jerman, Jepang dan Amerika Serikat Tahun 1995-2017

\begin{tabular}{lccc}
\hline \multirow{2}{*}{$\begin{array}{c}\text { Negara } \\
\text { Sumber } \\
\text { Impor }\end{array}$} & \multicolumn{3}{c}{$\begin{array}{c}\text { Nilai Rata-rata Share Kopi Biji } \\
\text { (persen) }\end{array}$} \\
\cline { 2 - 4 } & Jerman Jepang & $\begin{array}{c}\text { Amerika } \\
\text { Serikat }\end{array}$ \\
\hline Indonesia & 4,20 & 9,92 & 5,81 \\
Vietnam & 10,86 & 6,76 & 7,46 \\
\hline
\end{tabular}

Sumber: UN Comtrade Diolah, 2019

Adapun nilai rata-rata share impor kopi biji Indonesia dan Vietnam di negara importir yaitu Amerika Serikat, Jepang dan Jerman berdasarkan Tabel 1 dapat dilihat bahwa pangsa kopi biji Indonesia di Amerika Serikat, Jepang dan Jerman selama periode tahun 1995-2017 secara berturut-turut sebesar 4,20 persen, 9,92 persen dan 5,81 persen dari total impor kopi biji di masing-masing negara importir. Proporsi ini sangat kecil jika dibandingkan dengan pangsa impor kopi biji Vietnam sebagai negeri eksportir robusta terbesar di dunia.

Persaingan yang terjadi antara Indonesai dan Vietnam sebagai negara eksportir kopi robusta terbesar di dunia, meskipun sama-sama negara penghasil jenis kopi rosbusta kedua negara tersebut memiliki jumlah ekspor yang berbeda-beda pada tiap negara importir sehingga hal tersebut dapat menyebabkan perubahan posisi pasar suatu negara dalam waktu yang akan datang. Hal tersebut dikemukakan pada hasil penelitian Kustiari (2016); Drajat dkk. (2007); Zuhdi (2015), menyatakan bahwa kopi Indonesia mengalami peningkatan ekspor dan memiliki daya saing namun posisi kopi Indonesia masih berada pada posisi yang lemah jika dibandingkan negara eksportir kopi dunia lainnya. Selanjutnya Rosiana dkk (2017), menambahkan bahwa fluktuasi volume ekspor kopi di beberapa negara eksportir utama pada 15 tahun terakhir diduga akan berdampak pada posisi suatu negara dalam menghadapi kompetisi dengan negara eksportir lainnya. 
Faktor-faktor yang Memengaruhi Permintaan Kopi Biji di pasar Amerika Serikat

Hasil estimasi dari model AIDS digunakan untuk menganalisis faktor-faktor yang memengaruhi permintaan kopi Indonesia di pasar Amerika Serikat, Jepang dan Jerman sebagai negara importir utama. Terdapat beberapa variabel bebas pada model, diantaranya variabel Harga kopi Indonesia, Harga kopi Vietnam, Harga kopi rest of the world (row), Pengeluaran (Total nilai impor), Carea NTM (Sanitary and Phytosanitary/SPS dan Technical Barier to Trade/TBT), Populasi, Gross Domestic Product (GDP) rill per-kapita, Inflasi dan Nilai tukar riil. Tabel 2, menunjukkan hasil estimasi model AIDS kopi biji di pasar Amerika Serikat.

\begin{tabular}{|c|c|c|}
\hline \multicolumn{3}{|c|}{$\begin{array}{c}\text { Tabel } 2 \\
\text { Faktor-faktor yang Memengaruhi } \\
\text { Permintaan Kopi Biji di pasar } \\
\text { Amerika Serikat }\end{array}$} \\
\hline Variabel & Indonesia & Vietnam \\
\hline Intercep & $-0,26396$ & 0,42120 \\
\hline $\begin{array}{l}\text { Harga kopi } \\
\text { Indonesia }\end{array}$ & $-0,02077$ & 0,00089 \\
\hline $\begin{array}{l}\text { Harga kopi } \\
\text { Vietnam }\end{array}$ & $-0,00379$ & $-0,00379$ \\
\hline Harga row & $0,02456^{\star *}$ & $0,00290^{* *}$ \\
\hline Pengeluaran & 0,01197 & $-0,02425$ \\
\hline Carea NTM & $-0,04086^{*}$ & $-0,26269^{* *}$ \\
\hline Populasi & $-0,00055$ & $-0,00002$ \\
\hline $\begin{array}{l}\text { GDP rill } \\
\text { perkapita }\end{array}$ & $0,00498^{* *}$ & $0,00323^{* *}$ \\
\hline Inflasi & $-0,00067$ & 0,00112 \\
\hline
\end{tabular}

Keterangan: *) nyata pada taraf 10 persen $\left.(0,10),{ }^{* *}\right)$ nyata pada taraf 5 persen, $(0,05)$, $* \star *)$ nyata pada taraf 1 persen $(0,01)$

Sumber: UN Comtrade Diolah, 2019

Berdasarkan Tabel 2, dapat dilihat variabel yang memengaruhi proporsi impor kopi biji Indonesia di pasar Amerika Serikat adalah variabel harga row (harga kopi biji di Rest of the World) signifikan pada taraf nyata 5 persen dan tanda parameter positif dengan nilai 0,02456 , artinya jika harga kopi Rest of the World naik sebesar 10 persen maka proporsi kopi biji dari Indonesia akan naik sebesar 0,2456 persen di pasar Amerika Serikat. Kemudian variabel Carea NTM signifikan dengan taraf nyata 1 persen bertanda negatif dengan nilai $-0,04086$ artinya apabila terjadi peningkatan variabel non tarif massure (NTM) berupa SPS dan TBT di pasar Amerika Serikat sebesar 10 persen, maka akan menyebabkan turunnya proporsi kopi biji Indonesia sebesar 0,4086 persen. Selanjutnya variabel GDP rill perkapita signifikan pada taraf nyata 5 persen dan bertanda positif dengan nilai 0,00498 artinya jika terjadi kenaikan GDP rill perkapita Amerika Serikat sebesar 10 persen maka akan menyebabkan kenaikan proporsi permintaan kopi biji Indonesia sebesar 0,0498 di pasar Amerika Serikat.

Variabel yang memengaruhi proporsi impor kopi biji Vietnam di pasar Amerika Serikat adalah variabel harga row (harga kopi biji di Rest of the World) signifikan pada taraf nyata 5 persen dan tanda parameter positif dengan nilai 0,00290, artinya jika harga kopi Rest of the World naik sebesar 10 persen maka proporsi kopi biji dari Vietnam akan naik sebesar 0,0290 persen di pasar Amerika Serikat. Kemudian variabel Carea NTM signifikan dengan taraf nyata 5 persen bertanda negatif dengan nilai $-0,26269$ artinya apabila terjadi peningkatan variabel non tarif massure (NTM) berupa SPS dan TBT di pasar Amerika Serikat sebesar 10 persen, maka akan menyebabkan turunnya proporsi kopi biji Vietnam sebesar 2,6269 persen. Selanjutnya variabel GDP rill perkapita signifikan pada taraf nyata 5 persen dan bertanda positif dengan nilai 0,00323 artinya jika terjadi kenaikan GDP rill perkapita Amerika Serikat sebesar 10 persen maka akan menyebabkan kenaikan proporsi permintaan kopi biji Vietnam sebesar 0,0323 di pasar Amerika Serikat.

Hasil estimasi menunjukkan bahwa faktor-faktor yang memengaruhi proporsi kopi biji Indonesia ternyata memiliki variabel yang sama dengan kopi biji Vietnam di pasar Amerika Serikat. Rosiana dkk. (2017), menyatakan bahwa kopi Indonesia dan Vietnam sama-sama dominan berjenis 
robusta dengan share kopi biji Vietnam yang cenderung lebih tinggi daripada kopi biji Indonesia. Melihat persamaan faktorfaktor yang mempengaruhi proporsi impor untuk kopi Indonesia dan Vietnam maka dalam hal ini kopi biji dari Indonesia dan Vietnam dipengaruhi oleh faktor yang sama di Amerika Serikat karena jenis kopinya juga sama yaitu kopi robusta.

Faktor-faktor yang memengaruhi Permintaan Kopi Biji di Pasar Jepang

Jepang adalah negara yang memiliki jumlah impor kopi biji dari Indonesia yang mengalami trend cenderung naik setiap tahun. Hal ini akan menjadi peluang bagi Indonesia apabila dapat mempertahankan dan meningkatkan posisi pasarnya di Jepang. Hasil estimasi model AIDS kopi biji di pasar Jepang dapat dilihat pada Tabel 3.

Tabel 3

Faktor-faktor yang memengaruhi Permintaan Kopi Biji di Pasar Jepang

\begin{tabular}{|c|c|c|}
\hline Variabel & Indonesia & Vietnam \\
\hline Intercep & $-0,0968$ & 0,81292 \\
\hline $\begin{array}{l}\text { Harga kopi } \\
\text { Indonesia }\end{array}$ & $-0,0177$ & $0,04392^{* * *}$ \\
\hline Harga kopi Vietnam & $0,0439^{* * *}$ & $-0,00910$ \\
\hline Harga row & $-0,0262$ & $-0,03483^{* *}$ \\
\hline Pengeluaran & $-0,0352$ & $-0,01624$ \\
\hline Carea NTM & $-0,0584$ & $-0,61650^{*}$ \\
\hline Populasi Jepang & $0,0088^{* *}$ & $-0,00405^{\star *}$ \\
\hline $\begin{array}{l}\text { GDP rill perkapita } \\
\text { Jepang }\end{array}$ & $-0,0001$ & $0,00003^{* *}$ \\
\hline Inflasi Jepang & 0,0001 & 0,00023 \\
\hline $\begin{array}{l}\text { NTR Jepang } \\
\text { terhadap dolar }\end{array}$ & $0,0003^{* *}$ & $-0,00026$ \\
\hline
\end{tabular}

Keterangan: *) nyata pada taraf 10 persen $\left.(0,10),{ }^{* *}\right)$ nyata pada taraf 5 persen $\left.(0,05),{ }^{* * *}\right)$ nyata pada taraf 1 persen $(0,01)$

Sumber: UN Comtrade Diolah, 2019

Berdasarkan Tabel 3, dapat dilihat bahwa faktor-faktor yang mempengaruhi permintaan kopi biji Indonesia di pasar Jepang adalah variabel harga kopi Vietnam yang bertanda positif dan signifikan pada taraf nyata 10 persen dengan nilai 0,0439, artinya kenaikan harga kopi Vietnam sebesar 10 persen akan menyebabkan kenaikan proporsi impor kopi biji Jepang dari Indonesia sebesar 0,439. Selanjutnya, varabel populasi Jepang berpengaruh positif dan signifikan dengan taraf nyata 5 persen memiliki nilai sebesar 0,0088, artinya apabila terjadi kenaikan populasi Jepang sebesar 10 persen maka akan mengakibatkan terjadinya kenaikan permintaan kopi biji dari Indonesia sebesar 0,088 di pasar Jepang. Kemudian variabel NTR Jepang terhadap dolar berpengaruh positif dengan nilai signifikasi sebesar 0,0003 artinya peningkatan NTR Jepang terhadap dolar sebesar 10 persen akan menyebabkan kenaikan proporsi impor kopi biji Indonesia sebear 0,003 di pasar Jepang.

Faktor-faktor yang mempengaruhi kopi biji Indonesia dan Vietnam memiliki variabel yang sama dan juga berbeda, adapun faktor-faktor yang mempengaruhi permintaan kopi biji Vietnam di pasar Jepang adalah variabel harga kopi Vietnam yang bertanda positif dan signifikan pada taraf nyata 10 persen dengan nilai 0,0439, artinya kenaikan harga kopi Indonesia sebesar 10 persen akan menyebabkan kenaikan proporsi impor kopi biji Jepang dari Vietnam sebesar 0,439. Selanjutnya, varabel harga kopi row berpengaruh negatif dan signifikan dengan taraf nyata 5 persen memiliki nilai $-0,03483$, artinya apabila terjadi kenaikan harga kopi row sebesar 10 persen maka akan mengakibatkan terjadinya penurunan permintaan kopi biji dari Vietnam sebesar 0,3483 di pasar Jepang.

Kemudian variabel Carea NTM berpengaruh signifikan pada taraf nyata 1 persen dengan nilai $-0,61650$, artinya apabila terjadi peningkatan kebijakan non tarif berupa SPS dan TBT (Carea NTM) sebesar 10 persen di Jepang maka akan menyebabkan terjadinya penurunan proporsi impor kopi biji Vietnam sebesar 6,1650 di pasar Jepang. Selanjutnya, varabel populasi Jepang berpengaruh negatif dan signifikan dengan taraf nyata 5 persen memiliki nilai sebesar $-0,00405$, artinya apabila terjadi kenaikan populasi Jepang sebesar 10 persen maka akan 
mengakibatkan turunnya permintaan kopi biji dari Vietnam sebesar 0,0405 di pasar Jepang. Selanjutnya variabel GDP rill perkapita Jepang signifikan pada taraf nyata 5 persen dan bertanda positif dengan nilai 0,00003 artinya jika terjadi kenaikan GDP rill perkapita Jepang sebesar 10 persen maka akan menyebabkan kenaikan proporsi permintaan kopi biji Vietnam sebesar 0,0003 di pasar Jepang. Faktor penting yang berpengaruh terhadap aliran perdagangan Vietnam pernah diteliti oleh Nguyen (2010), mengemukakan bahwa ditemukan adanya korelasi aliran ekspor Vietnam tahun saat ini dengan tahun sebelumnya, Pertumbuhan ekspor Vietnam berpengaruh positif terhadap pertumbuhan pemasukan di negara mitra dagang.

Faktor-faktor yang Memengaruhi Permintaan Kopi Biji di Pasar Jerman

Hasil estimasi model AIDS mengenai Faktor-faktor yang memengaruhi Permintaan Kopi Biji di Pasar Jerman terdapat pada Tabel 4.

Tabel 4

Faktor-faktor yang memengaruhi Permintaan Kopi Biji di pasar Jerman

\begin{tabular}{lcc}
\hline Variabel & Indonesia & Vietnam \\
\hline Intercep & $-1,0188$ & $-2,9384$ \\
harga kopi Indonesia & 0,0033 & 0,0123 \\
Harga kopi Vietnam & 0,0123 & 0,0459 \\
Harga row & $-0,0156^{\star}$ & $-0,0582^{* *}$ \\
Pengeluaran & 0,0339 & 0,0804 \\
Carea NTM & $-0,1967^{\star *}$ & $-0,1117^{\star *}$ \\
Populasi Jerman & 0,0060 & $0,0129^{* *}$ \\
GDP rill perkapita & $-0,0035$ & $0,0126^{*}$ \\
Jerman & & \\
Inflasi Jerman & 0,0001 & 0,0018 \\
NTR Jerman & $-0,0147$ & $-0,0156$ \\
terhadap dolar & &
\end{tabular}

Keterangan: ${ }^{*}$ ) nyata pada taraf 10 persen $\left.(0,10),{ }^{* *}\right)$ nyata pada taraf 5 persen $\left.(0,05),{ }^{* * *}\right)$ nyata pada taraf 1 persen $(0,01)$

Sumber: UN Comtrade Diolah, 2019

Tabel 4, menunjukkan bahwa terdapat 2 variabel yang berpengaruh terhadap permintaan kopi biji di pasar Jerman yaitu variabel harga kopi row bertanda negatif dan signifikan pada taraf nyata 1 persen dengan nilai sebesar -0,0156, artinya apabila terjadi kenaikan harga kopi row sebesar 10 persen maka akan terjadi penurunan proporsi permintaan kopi biji dari Indonesia sebesar 0,156 di pasar Jerman. Selanjutnya variabel Carea NTM bernilai negatif dan signifikan pada taraf nyata sebesar 5 persen dengan nilai sebesar -0,1967. Artinya apabila terjadi peningkatan kebijakan non tarif berupa SPS dan TBT (Carea NTM) sebesar 10 persen di Jerman maka akan menyebabkan terjadinya penurunan proporsi impor kopi biji dari Indonesia sebesar 1,967 di pasar Jerman. Hal ini sejalan dengan studi sebelumnya yang dilakukan oleh Komaling (2013), diperolah hasil bahwa variabel pendapatan perkapita Jerman, kemudian harga kopi dunia serta konsumsi kopi Jerman ternyata berdampak signifikan terhadap volume ekspor kopi Indonesia ke Jerman.

Faktor-faktor yang memengaruhi kopi biji Indonesia dan Vietnam memiliki variabel yang sama dan juga berbeda di pasar Jerman, adapun faktor-faktor yang mempengaruhi permintaan kopi biji Vietnam di pasar Jerman adalah variabel harga kopi row bertanda negatif dan signifikan pada taraf nyata 5 persen dengan nilai -0,0582, artinya kenaikan harga kopi row sebesar 10 persen akan menyebabkan turunnya permintaan impor kopi Vietnam sebesar 1,117 di pasar Jerman, hasil penelitian ini sejalan dengan penelitian Hong (2016), tentang pengaruh nilai tukar dan harga dunia terhadap harga ekpor kopi Vietnam. Variabel Carea NTM bertanda negatif dan signifikan pada taraf nyata 5 persen dengan nilai $-0,1117$, artinya apabila terjadi peningkatan kebijakan non tarif berupa SPS dan TBT (Carea NTM) sebesar 10 persen di Jerman maka akan menyebabkan terjadinya penurunan proporsi impor kopi biji Vietnam sebesar 1,117 di pasar Jerman. Kemudian variabel populasi Jerman bertanda positif dan signifikan pada taraf nyata 5 persen dengan nilai 0,0129 , artinya apabila terjadi 
kenaikan populasi sebesar 10 persen di Jerman, maka akan mengakibatkan terjadinya kenaikan proporsi impor kopi biji sebesar 0,129 dari Vietnam di pasar Jerman. Selanjutnya variabel GDP rill perkapita Jerman bertanda positif dan signifikan pada taraf nyata 1 persen dengan nilai 0,0126 , artinya apabila terjadi kenaikan GDP rill perkapita Jerman sebesar 10 persen, maka akan mengakibatkan terjadinya kenaikan proporsi impor kopi biji sebesar 0,126 persen dari Vietnam di pasar Jerman.

\section{Elastisitas Permintaan Kopi Indonesia} Perhitungan elastisitas pada penelitian ini menggunakan elastisitas permintaan Marshallian (uncompensated) dimana terdiri dari elastisitas harga sendiri, kemudian elastisitas harga silang dan yang terakhir adalah elastisitas pengeluaran. Hasil perhitungan ketiga elastisitas tersebut dibahas berdasarkan jenis kopi yang dianalisis.

\section{Elastisitas Harga Sendiri}

Nilai elastisitas harga sendiri (mutlak) yang menunjukkan lebih besar atau sama dengan $1(\varepsilon \geq|1|)$ menunjukkan bahwa kopi tersebut bersifat elastis, sebaliknya nilai elastisitas harga sendiri (mutlak) yang kurang dari $1(\varepsilon<|1|)$ menunjukkan bahwa kopi tersebut bersifat inelastis. Berikut hasil elastisitas permintaan kopi biji Indonesia dan Vietnam di negara Amerika Serikat, Jepang dan Jerman terdapat pada Tabel 5.

\section{Tabel 5}

Elastisitas Harga Sendiri Kopi Biji Indonesia dan Vietnam di Amerika Serikat, Jepang dan Jerman

\begin{tabular}{llll}
\hline \multirow{2}{*}{$\begin{array}{c}\text { Negara } \\
\text { Eksportir }\end{array}$} & \multicolumn{3}{c}{ Negara Importir } \\
\cline { 2 - 4 } & $\begin{array}{c}\text { Amerika } \\
\text { Serikat }\end{array}$ & Jepang & Jerman \\
\hline Indonesia & $-1,38$ & $-1,14$ & $-0,95$ \\
Vietnam & $-1,03$ & $-1,12$ & -0.65 \\
\hline Sumber: UN & Comtrade & Diolah, 2019
\end{tabular}

Dari nilai elastisitas di pasar Amerika Serikat, elastisitas harga sendiri kopi biji Indonesia adalah yang paling tinggi, yaitu $-1,38$ (elastis). Situasi ini sebenarnya tidak begitu menguntungkan bagi Indonesia karena jika terjadi perubahan harga kopi biji dari Indonesia, maka perubahan permintaan kopi biji di Amerika Serikat akan semakin responsif. Jika harga kopi biji impor masing-masing negara naik sebesar 10 persen, maka penurunan permintaan paling besar adalah impor kopi biji dari Indonesia sebesar 13,8 persen sementara penurunan impor kopi biji dari Vietnam turun sebesar 10,3 persen dan nilai ini lebih kecil dibandingkan dengan elastisitas kopi biji Indonesia. Hal ini menunjukkan bahwa kopi biji Vietnam masih menjadi pilihan utama daripada kopi biji Indonesia di pasar Amerika Serikat.

Di pasar Jepang, kopi biji Indonesia dan Vietnam sama-sama bersifat elastis dengan nilai elastisitas kopi biji Indonesia sebesar -1,14 dan kopi biji Vietnam sebesar $-1,12$, yang artinya jika terjadi kenaikan harga kopi Indonesia sebesar 10 persen maka akan menurunkan permintaan kopi Jerman dari Indonesia hingga 11,4 persen, sementara kopi Vietnam hanya 11,2 persen. Jelas terlihat bahwa kopi biji Vietnam masih menjadi pilihan utama daripada kopi biji Indonesia di pasar Jepang.

Di pasar Jerman, kopi biji Indonesia dan Vietnam sama-sama bersifat inelastic, dimana kopi biji Indonesia bersifat inelastis dengan nilai sebesar -0,95 dan kopi biji Vietnam bersifat inelastis dengan nilai sebesar $-0,65$, yang artinya berapapun kenaikan harga yang terjadi pada kopi biji Indonesia dan Vietnam tidak terlalu berpengaruh terhadap permintaan impor di pasar Jerman, namun jika dilihat lebih lanjut bahwa kopi biji Vietnam lebih inelastic dengan nilai sebesar -6,50 dibandingkan dengan kopi biji Indonesia dengan nilai $-0,95$.

Berdasarkan nilai elastisitas harga sendiri dapat dilihat bahwa kopi biji Indonesia lebih elastis jika dibanding dengan kopi biji Vietnam di pasar Amerika Serikat dan Jepang, sementara di pasar Jerman kopi biji Vietnam bersifat lebih inelastis jika dibanding dengan kopi biji Indonesia. 
Elastisitas Silang

Elastisitas silang dari Kopi Biji Indonesia dan Vietnam di Amerika Serikat dapat dilihat pada Tabel 6.

\section{Tabel 6}

Elastisitas Harga Silang Kopi Biji Indonesia dan Vietnam di Amerika Serikat

\begin{tabular}{lll}
\hline \multicolumn{1}{c}{ Negara Eksportir } & \multicolumn{2}{c}{ Elastisitas Silang } \\
& Indonesia & Vietnam \\
\hline Indonesia & $-0,01$ \\
Vietnam & $-0,32$ & \\
\hline
\end{tabular}

Kopi biji Indonesia dan Vietnam di pasar Amerika Serikat bersifat inelastis dengan nilai elastisitas kurang dari satu $(\varepsilon<1)$, kedua negara menujukkan nilai sama-sama bertanda negatif dimana tanda ini berarti hubungan keduanya bersifat komplementer. Jika terjadi kenaikan harga kopi biji Indonesia sebesar 10 persen menyebabkan penurunan permintaan kopi Vietnam sebesar 0,1 persen di pasar Amerika Serikat dan jika terjadi kenaikan harga kopi biji Vietnam sebesar 10 persen akan menurunkan permintaan kopi Indonesia sebesar 3,2 persen di pasar Amerika Serikat. Hal ini menunjukkan perubahan harga kopi biji Indonesia dan Vietnam di pasar Amerika Serikat bersifat komplementer dari nilai elastisitasnya dapat dilihat perubahan yang paling banyak mengalami penurunan apabila terjadi kenaikan harga adalah penurunan terhadap permintaan kopi biji Indonesia yaitu sebesar 3,2 persen dibandingkan dengan kopi biji Vietnam hanya sebesar 0,1 persen di pasar Amerika Serikat. Studi sebelumnya tentang permintaan kopi di Amerika Serikat menemukan bahwa elastisitas silang kopi bersifat inelasti (Okunade, 1992).

Dengan demikian posisi tawar Indonesia terkait harga relatif lemah dibandingkan dengan Vietnam. Kondisi ini menunjukkan bahwa Indonesia harus dapat meningkatkan kualitas kopi yang di ekspor ke negara importir khususnya
Amerika Serikat (Drajat dkk., 2007; Sinta dkk., 2017). Peningkatan kualitas dimulai dari pemilihan bibit unggul, pemeliharaan pohon kopi, pemetikan buah kopi yang sesuai dengan tingkat kematangannya, pengeringan biji kopi serta melalui penerapan sertifikasi pada komoditas kopi Indonesia (Asmarantaka, 2011; Baroh dkk., 2014; Fadah \& Handriyono, 2016; Sinta dkk., 2017). Hal ini akan mendukung peningkatan kemampuan bersaing dari kopi Indonesia di pasar Internasional.

Selanjutnya analisis elastisitas harga silang kopi biji Indonesia dan Vietnam di pasar Jepang dapat dilihat pada Tabel 7.

Tabel 7

Elastisitas Harga Silang Kopi Biji Indonesia dan Vietnam di Jepang

\begin{tabular}{lcc}
\hline \multirow{2}{*}{ Negara Eksportir } & \multicolumn{2}{c}{ Elastisitas Silang } \\
\cline { 2 - 3 } & Indonesia & Vietnam \\
\hline Indonesia & & 0,68 \\
Vietnam & 0,44 & \\
\hline
\end{tabular}

Sumber: UN Comtrade Diolah, 2019

Kopi biji Indonesia dan Vietnam di pasar Amerika Serikat bersifat inelastis dengan Nilai elastisitas kurang dari satu $(\varepsilon<1)$, kopi biji Indonesia bersaing dengan Vietnam di pasar Jepang, hal ini ditunjukkan dengan nilai elastisitas silang yang positif artinya bersifat substitusi kenaikan harga kopi biji Indonesia sebesar 10 persen menyebabkan kenaikan permintaan kopi biji Vietnam sebesar 6,8 persen di pasar Jepang, demikian halnya dengan kenaikan harga kopi biji Vietnam 10 persen akan meningkatkan permintaan kopi Indonesia sebesar 4,4 persen. Dalam hal ini dapat diuraikan lebih lanjut bahwa kopi biji Indonesia bersifat substitusi dengan kopi biji Vietnam di pasar Jepang, sehingga kenaikan harga kopi biji Indonesia akan mempengaruhi kenaikan yang terjadi pada kopi Vietnam di pasar Jepang dan demikian sebaliknya, berdasarkan nilai elastisitas silang menunjukkan bahwa perubahan harga kopi biji Indonesia akan lebih memberikan keuntungan bagi kopi biji Vietnam dengan perubahan jumlah 
permintaan kopi biji yang lebih tinggi di pasar Jepang.

Kemudian analisis elastisitas harga silang kopi biji Indonesia dan Vietnam di pasar Jerman dapat dilihat pada Tabel 8.

\section{Tabel 8}

Elastisitas Harga Silang Kopi Biji Indonesia dan Vietnam di Jerman

\begin{tabular}{llc}
\hline \multirow{2}{*}{ Negara Eksportir } & \multicolumn{2}{c}{ Elastisitas Silang } \\
\cline { 2 - 3 } & Indonesia & Vietnam \\
\hline Indonesia & \multicolumn{1}{c}{0,08} \\
Vietnam & 0,30 & \\
\hline
\end{tabular}

Sumber: UN Comtrade Diolah, 2019

Kopi biji Indonesia dan Vietnam di pasar Amerika Serikat bersifat inelastis dengan Nilai elastisitas kurang dari satu $(\varepsilon<1)$, Jika terjadi kenaikan harga kopi biji Indonesia sebesar 10 persen menyebabkan kenaikan permintaan kopi biji Vietnam sebesar 0,8 persen di pasar Jepang, demikian halnya dengan kenaikan harga kopi biji Vietnam 10 persen akan meningkatkan permintaan kopi Indonesia sebesar 3 persen. Dalam hal ini dapat diuraikan lebih lanjut bahwa kopi biji Indonesia bersifat substitusi dengan kopi biji Vietnam di pasar Jerman, sehingga kenaikan harga kopi biji Indonesia akan mempengaruhi kenaikan yang terjadi pada kopi Vietnam di pasar Jerman dan demikian sebaliknya, berdasarkan nilai elastisitas silang menunjukkan bahwa perubahan harga akan memberikan keuntungan bagi kopi biji Indonesia dengan perubahan jumlah permintaan kopi biji yang lebih tinggi di pasar Jerman apabila terjadi kenaikan harga kopi biji Vietnam.

\section{Elastisitas Pengeluaran}

Nilai Elastisitas pengeluaran kopi biji Indonesia dan Vietnam di Amerika Serikat, Jepang dan Jerman dapat dilihat pada Tabel 9.

Pada ketiga pasar tujuan ekspor kopi biji Indonesia dan Vietnam menunjukkan bahwa apabila terjadi penambahan pengeluaran di negara Amerika Serikat dan Jerman maka kedua negara tersebut cenderung memilih kopi biji dari Indonesia dibandingkan dari Vietnam, hal ini dapat dilihat pada nilai elastisitas pengeluaran kopi biji Indonesia yang lebih tinggi daripada nilai elastisitas kopi biji Vietnam di pasar Amerika Serikat dan Jerman, sementara di pasar Jepang apabila terjadi penambahan pengeluaran maka Jepang cenderung memilih impor kopi biji dari Vietnam (nilai elastisitas pengeluaran 0,76 ) dibandingkan Indonesia (nilai elastisitas pengeluaran 0,65 ) dan nilai elastisitas pengeluaran ini menunjukkan bahwa kopi biji Indonesia dan Vietnam di pasar importir utama adalah barang normal.

Tabel 9

Elastisitas Pengeluaran Kopi Biji Indonesia dan Vietnam di Amerika Serikat, Jepang dan Jerman

\begin{tabular}{llll}
\hline \multirow{2}{*}{ Negara } & \multicolumn{3}{c}{ Negara Importir } \\
\cline { 2 - 4 } Eksportir & $\begin{array}{c}\text { Amerika } \\
\text { Serikat }\end{array}$ & Jepang & Jerman \\
\hline Indonesia & 1,21 & 0,65 & 1,82 \\
Vietnam & 0,67 & 0,76 & 1,76 \\
\hline
\end{tabular}

Sumber: UN Comtrade Diolah, 2019

Berdasarkan uraian di atas, dapat dilihat dalam hal implikasi kebijakan dan stategi perdagangan kopi Indonesia di pasar Internasional seharusnya mengandung tiga aspek utama yaitu harga, kualitas dan tujuan pasar potensial. Dalam hal harga dapat difokuskan pada pengendalian kompetisi harga kopi biji Indonesia pada ketiga pasar tujuan karena dari nilai elastisitas harga sendiri diperoleh bahwa nilai kopi biji Indonesia yang lebih responsif dibandingkan kopi biji Vietnam. Analisis yang diperoleh dalam penelitian ini menunjukkan bahwa ketiga negara importir yang menjadi tujuan ekspor kopi Indonesia masih berpotensi bagi Indonesia, berdasarkan nilai elastisitas silang menunjukkan bahwa pasar yang paling potensial adalah pasar Jerman, Jepang kemudian Amerika Serikat. Hal ini dapat dimanfaatkan Indonesia untuk meningkatkan ekspornya dengan prioritas utama ke pasar yang lebih potensial. 


\section{SIMPULAN}

Berdasarkan pembahasan yang telah diuraikan, maka dapat disimpulkan bahwa faktor-faktor yang memengaruhi permintaan kopi biji Indonesia di pasar Amerika Serikat adalah harga kopi row, Carea NTM, sementara di pasar Jepang adalah harga kopi Vietnam, populasi Jepang dan NTR Jepang terhadap Dollar, sementara di pasar Jerman adalah harga row dan Carea NTM. Nilai elastisitas harga sendiri menunjukkan bahwa kopi biji Indonesia bersifat elastis di negara importir utama Amerika Serikat, Jepang dan Jerman. Kemudian berdasarkan nilai elastisitas silang diperoleh bahwa kopi biji Indonesia bersifat inelastis pada ketiga negara importir utama jika dibandingkan dengan negara pesaing yaitu Vietnam maka kopi biji Indonesia bersifat komplementer dengan kopi biji Vietnam di pasar Amerika Serikat, sementara di pasar Jepang dan Jerman bersifat substitusi. Berdasarkan elastisitas pengeluaran diperoleh bahwa kopi biji Indonesia dan Vietnam adalah barang normal di negara importir.

\section{DAFTAR PUSTAKA}

Direktorat Jenderal Perkebunan. (2015). Statistik Perkebunan Indonesia. Direktorat Jenderal Perkebunan.

$\begin{array}{ccc}\text { Kementerian } & \begin{array}{c}\text { Pertanian } \\ \text { Indonesia. }\end{array} & \begin{array}{r}\text { Republik } \\ \text { Renstra }\end{array} \\ \text { Kementan. Journal of Chemical } & \text { Chemion } \\ \text { Information and Modeling, 53(9), } \\ \text { 1689-1699. https://doi.org/10.1017/ } \\ \text { CBO9781107415324.004 }\end{array}$

Kementerian Pertanian Republik Indonesia. (2017). Guidelines On Phytosanitary Certification Of Export Commodity Of Indonesia. Seri Pedoman Sertifikasi Fitosanitari Komoditas Ekspor Indonesia, 1.0 (pedoman sertifikasi fitosanitari tembakau), 17-33.
Almeida, F. M. De, Gomes, F. M. M., \& Monteiro da Silva, O. (2012). Nontariff measures in international coffee trade. International Association of Agricultural Economists (IAAE) Triennial Conference, (June 2014).

Asmarantaka, R. W. (IPB). (2011). RatnaWinandi-Analisis-Dayasaing-EksporKopi-Indonesia.pdf.

Baroh, I., Hanani, N., Setiawan, B., \& Koestiono, D. (2014). Indonesian Coffee Competitiveness in the International Market: Armington Model Application. 4(4), 184194. https://doi.org/10.5923/j. economics.20140404.03

Deaton, A. S. (1980). The Theory and Measurement of Consumer Behaviour (Vol. 49).

Drajat, B., Agustian, A., \& Supriatna, A. (2007). Export and Competitiveness of Indonesian Coffee Bean in International Market: Strategic Implication for the Development of Organic Coffee Bean. Pelita Perkebunan (a Coffee and Cocoa Research Journal), 23(2), 159-179. https://doi.org/10.22302/iccri.jur. pelitaperkebunan.v23i2.88

Fadah, I., \& Handriyono. (2016). Potential And Problems Of Small And Large Scale Processed Coffee Businesses In Jember Regency. Review of Integrative Business \& Economics, 5(2), 105-113.

Galarraga, I., \& Markandya, A. (2004). Economic Techniques to Estimate the Demand for Sustainable Products: A Case Study for Fair Trade and Organic Coffee in the United Kingdom. Economia Agraria y Recursos Naturales, 4(7), 109-134. https://doi.org/10.7201/ earn.2004.07.06 
Gebrehiwot, W., \& Daloonpate, A. (2012). Demand analysis of Ethiopian coffee in Japan. Kasetsart Journal - Social Sciences, 33(1), 142-151.

Hidayat, A., \& Soetriono. (2010). Daya Saing Ekspor Kopi Robusta Indonesia Di Pasar Internasional. J-Sep, 4(2), 62-82. Retrieved from http://download.portalgaruda.org/ article. php? article $=95440 \&$ val $=5046$

Hong, T. T. K. (2016). Effects of exchange rate and world prices on export price of Vietnamese coffee. International Journal of Economics and Financial Issues, 6(4), 1756-1759.

Komaling, R. (2013). Analisis Determinan Ekspor Kopi Indonesia Ke Jerman Periode 1993-2011. Jurnal Riset Ekonomi, Manajemen, Bisnis Dan Akuntansi, 1(4), 2025-2035.

Kustiari, R. (2016). Perkembangan Pasar Kopi Dunia dan Implikasinya bagi Indonesia. Forum Penelitian Agro Ekonomi, 25(1), 43. https://doi. org/10.21082/fae.v25n1.2007.43-55

Narulita, S., Winandi, R., \& Jahroh, S. (2014). Analisis Dayasaing Dan Strategi Pengembangan Agribisnis Kopi Indonesia. Jurnal Agribisnis Indonesia, 2(1), 63. https://doi. org/10.29244/jai.2014.2.1.63-74

Nguyen, B. X. (2010). The Determinants of Vietnamese Export Flows: Static and Dynamic Panel Gravity Approaches. International Journal of Economics and Finance, 2(4), 122-129. https:// doi.org/10.5539/ijef.v2n4p122

Okunade, A. A. (1992). Functional forms and habit effects in the US demand for coffee. Applied Economics, 24(11), 1203-1212. https://doi. org/10.1080/00036849200000130
Rifin, A. (2010). Rifin. Export Competitiveness of Indonesia's Palm Oil Product. https://doi. org/10.1002/0471684228.egp10932

Rosiana, Nia., Nurmalina, Rita., Winandi, Ratna., Rifin, A. (2017). The Level of Comparative Advantages of World Main Coffee Producers Tingkat Keunggulan Komparatif Produsen Utama Kopi Dunia The growth of world coffee consumption was faster than the world coffee production during the period of The level of a ( ICO, style. 227-246.

Rosiana, N. (2019). Dayasaing dan Ekspor Kopi Indonesia.

Sinta, N. M., Alamsyah, Z., \& Elwamendri. (2017). Analisis Daya Saing Ekspor. Jurnal IImiah Sosio Ekonomika Bisnis, 20(1).

UN Comtrade. (2019). Un Comtrade.

Wilkinson, R. K., Deaton, A., \& Muellbauer, J. (1981). Economics and Consumer Behaviour. Journal of the Royal Statistical Society. Series A (General), 144, 538. https://doi. org/10.2307/2981834

Zuhdi, F, S. (2015). Analisis Daya Saing Ekspor Kopi Indonesia Dan Vietnam Di Pasar Asean. Jurnal IImiah SosioEkonomika Bisnis, 20(1), 3. https:// doi.org/10.22437/jiseb.v20i1.5028 